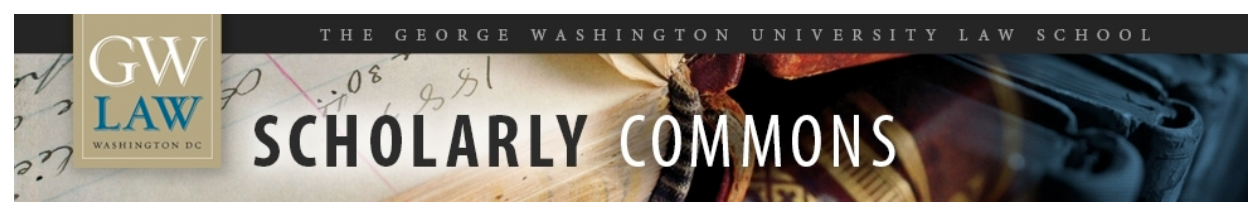

\title{
Racial Disparities and the Political Function of Property
}

Spencer A. Overton

George Washington University Law School, soverton@law.gwu.edu

Follow this and additional works at: https://scholarship.law.gwu.edu/faculty_publications

Part of the Law Commons

\section{Recommended Citation}

Spencer Overton, Racial Disparities and the Political Function of Property, 49 UCLA L. Rev. 1553 (2002).

This Article is brought to you for free and open access by the Faculty Scholarship at Scholarly Commons. It has been accepted for inclusion in GW Law Faculty Publications \& Other Works by an authorized administrator of Scholarly Commons. For more information, please contact spagel@law.gwu.edu. 


\title{
RACIAL DISPARITIES \\ AND THE POLITICAL FUNCTION OF PROPERTY
}

\author{
Spencer Overton ${ }^{*}$
}

\begin{abstract}
Race theorists have noted that racial discrimination has shaped the existing distribution of economic resources, and have used this observation to justify reparations, to defend affirmative action, and to call for other legal changes that would improve the socioeconomic status of people of color. This Article takes the theorists' observation further. Property has a political function. Racially discriminatory allocation rules not only impose economic and social harms upon people of color, but also impair the ability of these people to engage in political expression and participation through structures such as the privately financed campaign finance system.
\end{abstract}

\section{TABLE OF CONTENTS}

INTRODUCTION

I. RACE THEORY AND PROPERTY ............................................................................

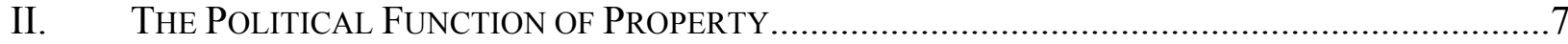

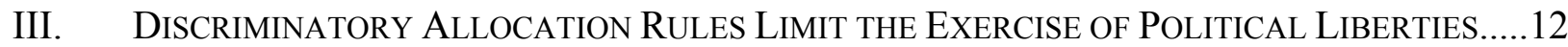

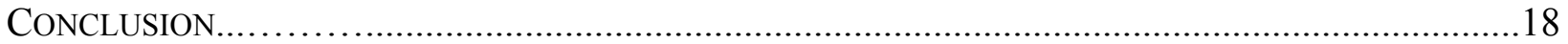

\footnotetext{
${ }^{1}$ Acting Professor of Law, University of California, Davis. A number of people read earlier versions or sections of this Article and provided helpful comments, including C. Edwin Baker, Leonard Baynes, Richard Delgado, Kevin Johnson, Ellen Katz, Frank Michelman, Cynthia Overton, Leslie Overton, Joseph Singer, Fane Wolfer, and Tobias Wolff. This Article also benefited from my exchanges with Anupam Chander, and from the outstanding research assistance of Shelley Bryant and Johanna Berta. Special thanks to Devon Carbado. The Article is dedicated to the memory of Kenneth Hylton, Jr., an outstanding friend, mentor, and public-minded lawyer.
} 


\section{INTRODUCTION}

Originally grounded in an examination of civil and political inequalities, race literature has expanded in scope. Critical race theorists have begun to raise incisive questions about the origins of the massive social and economic disparities that persist to this day, issuing powerful calls for corrective efforts at redistribution like affirmative action and reparations. This development is a salutary one. But it is not only in the realm of social and economic disparities that this connection between past wrong and present impact is necessary. The economic disparities that arise from past discriminatory policies limit not only substantive rights to control economic resources and enjoy educational and employment opportunities, but also political rights to participate in the democratic process. ${ }^{2}$

This Article focuses on the current privately-funded campaign finance system to illustrate how the distribution of private property creates racial disparities in the political sphere. In Buckley v. Valeo, ${ }^{3}$ the U.S. Supreme Court, concluding that money is needed for effective speech, curtailed the extent to which legislatures may restrict campaign contributions and spending on political activity. Discriminatory laws that have shaped the existing distribution of resources, ${ }^{4}$ however, also restrict individual political expression and association. Studies reveal that although people of color comprise approximately $30 \%$ of the nation's population, ${ }^{5}$ they represent only about $1 \%$ of those who make significant political contributions to federal campaigns. ${ }^{6}$ In a political system that deems money to be necessary for effective speech, the allocation of economic resources shapes the distribution of political power no less than the location of the boundary lines that define legislative districts.

${ }^{2}$ Cf. John Hart Ely, Democracy and Distrust: A Theory of Judicial Review 74-75, 75 n.* (1980) (distinguishing judicial review of substantive values, or "the designation of certain goods (rights or whatever)," from judicial review of process values, which "concerns itself with how decisions effecting value choices and distributing the resultant costs and benefits are made."). ${ }^{3} 424$ U.S. 1 (1976).

${ }^{4}$ For example, typical white households control an income stream that is about $156 \%$ of that which is controlled by both African American and Latino households. See U.S. Bureau of the Census, Money InCOME IN the United States: 1995, at viii (1996) (finding that in 1995, median household income was $\$ 35,766$ for whites, $\$ 22,860$ for Latinos, and $\$ 22,391$ for African Americans). White households also possess a median net worth that is over eight times greater than that of African American households and over twelve times greater than that of Latino households. See CHuck Collins, Betsy LeONDAR-Wright \& Holly Sklar, Shifting fortunes: The Perils of the Growing American Wealth Gap 57 (1999) (finding that in 1995, the median household net worth for whites was $\$ 61,000$, for African Americans was $\$ 7,400$, and for Hispanics was $\$ 5,000$, and that the financial wealth (net worth minus equity in owner-occupied housing) for the typical white household was $\$ 18,000$, for African-Americans was \$200, and for Hispanics zero).

${ }^{5}$ See U.S. Bureau of the Census, Resident Population Estimates of the United States by Sex, Race, and Hispanic Origin: April 1, 1990 to July 1, 1999, with Short-Term Projection to November 1, 2000, at 1 (2000) [hereinafter Census Population Estimates] (indicating that as of November 1, 2000, African Americans made up 12.8\%, Hispanics 11.9\%, Asian Americans 4.1\%, and American Indians, Eskimos, and Aleuts $0.9 \%$ of the population of the United States).

${ }^{6}$ See John Green, Paul Herrnson, Lynda Powell \& Clyde Wilcox, Individual Congressional Campaign Contributors: Wealthy, Conservative and Reform-Minded, Individual Donors and Campaign Finance, JOYCE FoundATION, 1998, at 13 (surveying individuals who made contributions of over \$200 to federal campaigns, and showing that less than $1 \%$ of contributors surveyed identified themselves as people of color, whereas $95 \%$ indicated they are white. 
This Article does not promote or defend a particular remedy to this problem, such as reparations, affirmative action, or publicly financed campaigns. ${ }^{7}$ Also beyond the scope of this Article are questions related to the significance of individual responsibility, the political feasibility and mechanics of remedial devices, and the constitutionality of such devices. ${ }^{8}$

Instead, this Article illuminates the political function of property rights and asserts that discriminatory laws that impact the distribution of economic resources also affect the ability of people of color to exercise political liberties. ${ }^{9}$ The impairment of political rights may be among the most troubling effects of discriminatory policies that have shaped the distribution of property, as political rights allow individuals to secure and preserve other substantive rights and opportunities. ${ }^{10}$ Political rights also give individuals a sense of full citizenship within a community $^{11}$ and serve as a "vehicle for self-development and identification, and a means for creating alliances." 12

${ }^{7}$ For a discussion of possible remedies in the campaign finance context, including application of the Voting Rights Act and an
analysis of various campaign finance reform proposals, see Spencer A. Overton, But Some Are More Equal: Race, Exclusion,
and Campaign Finance, 80 TEX. L. REV. (forthcoming 2002). Note that legislation recently passed by Congress will not prevent
the existing distribution of private wealth from creating racial disparities in the political sphere. While the Bipartisan Campaign
Reform Act of 2002 bans unlimited "soft" money contributions, the bill increases the amount of money an individual can give to
a federal candidate to $\$ 2,000$ from $\$ 1,000$. See S. 27,107 th Cong., $1^{\text {st }}$ Sess. $\S 323(2001)$ (banning soft money); H.R. 2356 ,
107 th Cong., $1^{\text {st }}$ Sess. $\S 323(2002)$ (same); S. 27,107 th Cong., $1^{\text {st }}$ Sess. $\S 308(a)(1)(2001)$ (doubling the amount of money an
individual can contribute to a federal candidate from $\$ 1,000$ to $\$ 2,000) ;$ H.R. 2356, 107th Cong., $1^{\text {st }}$ Sess. $\S 307(a)(1)(2002)$
(same).

${ }^{8}$ Some might argue that the U.S. Supreme Court would invalidate race-conscious remedial devices enacted to address historical and societal discrimination. See City of Richmond v. J.A. Croson Co., 488 U.S. 469, 521 (1989) (Scalia, J., concurring) (arguing that "our Constitution is color-blind"). But see Regents of University of California v. Bakke, 438 U.S. 265, 336 (1978) (Brennan, White, Marshall, and Blackmun, JJ., dissenting in part and concurring in part) (noting that "no decision of this Court has ever adopted the proposition that the Constitution must be colorblind"). The Court has, in some cases, minimized the importance of past discrimination in its constitutional analysis. See Wygant v. Jackson Bd. of Educ. 476 U.S. 267, 276 (1985) ("[S]ocietal discrimination, without more, is too amorphous a basis for imposing a racially classified remedy."); Richmond v. Croson, 488 U.S. 469, 499 (1989) ("While there is no doubt that the sorry history of both private and public discrimination in this country has contributed to a lack of opportunities for black entrepreneurs, this observation, standing alone, cannot justify a rigid racial quota in the awarding of public contracts in Richmond, Virginia."). In other cases, however, the Court has acknowledged the current impact of past discrimination. See Gaston County v. United States, 395 U.S. 285, 291, 293 n.9 (1969) (invalidating county's literacy test in part because the county's previous maintenance of a de jure segregated school system had "deprived its black residents of equal educational opportunities, which in turn deprived them of an equal chance to pass the literacy test," and finding "no legal significance" to the county's claim that some residents unable to pass the test were educated in other jurisdictions that maintained unequal school systems).

${ }^{9}$ This Article focuses on the reality that, under current jurisprudence, the distribution of property affects the value of political liberties, and that critical race theorists should consider this reality when they make claims for distributive justice. Other works by the author use the lens of race to analyze campaign finance empirical data, constitutional issues, and reform legislation. See Spencer Overton, Voices From the Past: Race, Privilege, and Campaign Finance, 79 N.C.L. Rev. 1541 (2001) (providing extensive data and discussion on the connection between past racial discrimination, existing income, wealth, and poverty statistics, and current contributions); Spencer A. Overton, But Some Are More Equal: Race, Exclusion, and Campaign Finance, 80 TEX. L. REV. (forthcoming 2002) (criticizing mainstream campaign finance reformers for ignoring racial realities connected to the distribution of property in their constitutional critique of existing jurisprudence and in their reform proposals).

${ }^{10} \mathrm{Cf}$. Yick Wo v. Hopkins, 118 U.S. 356, 370 (1886) (noting that the political franchise "is regarded as a fundamental political right, because [it is] preservative of all rights"); Katzenbach v. Morgan, 384 U.S. 641, 652 (1966) ("[P]olitical power [can] be helpful in gaining nondiscriminatory treatment in public services for [an entire minority] community.").

${ }^{11}$ See Pamela S. Karlan, Undoing the Right Thing: Single-Member Offices and the Voting Rights Act, 77 VA. L. REV. 1, 5 (1991) (noting that voting "announces that the voter is a full member of the political community"); KENNETH L. KARST, BELONGING TO AMERICA: EQUAL Citizenship AND THE CONSTITUTION 93 (1989) ("Voting . . . is an assertion of belonging to a political community.”); Quiet Revolution in the South: The ImPact of the Voting Rights Act 1965-1990, at 15-16 (Chandler Davidson \& Bernard Grofman eds., 1994) (noting that the right to vote "confer[s] full citizenship on the members of the group"); Lani Guinier, Voting Rights and Democratic Theory: Where Do We Go From Here?, in CONTROVERSIES IN MINORITY VOTING: 
This Article complements rather than subverts race theorists' efforts to emphasize socioeconomic disparities, for a recognition of how property rights function in the political arena leads to more comprehensive discussion about the racial misallocation of economic resources. Theorists can more clearly articulate the consequences of past discriminatory policies and tailor remedies to address these consequences. Indeed, discussions about political process may allow for meaningful exchange and progress when discussions about substantive entitlements are stalled, as many who tolerate economic disparities along racial lines may be less comfortable with political disparities. ${ }^{13}$ Finally, an acknowledgment of the political function of property pierces the veil between wealthy private actors and facially race-neutral state actions that effectively perpetuate, and often exacerbate, racial disparities.

Part I of this Article reviews the literature of theorists who connect past discrimination to existing economic and social disparities. Part II examines the link between the exercise of property rights and effective political participation that served as the foundation of the Court's decision in Buckley v. Valeo. Part III explains that liberties are suppressed not only by government restrictions on the use and conveyance of resources on politics, but also by allocation rules that determine how decisonmaking authority over particular resources is ordered and distributed. Past discriminatory allocation rules hinder the extent to which many people of color contribute money to political campaigns and spend money on political expression. These rules also limit the extent to which people of color exercise political liberties in other contexts. For example, discriminatory allocation rules influence the ownership of media outlets, access to quality voting technology, and a host of other legal relationships that provide a greater opportunity to exercise political liberties to select populations.

\footnotetext{
The Voting Rights Act in Perspective 283, 284-85 (Bernard Grofman \& Chandler Davidson eds., 1993) (The Voting Rights Act "is premised on a broad vision of political equality and empowerment . . . that would value political participation for its own sake in order to recognize the autonomy and dignity of black voters. Participation would affirm their status as first-class citizens in a democracy.").

${ }^{12}$ Ellen D. Katz, Race and the Right to Vote After Rice v. Cayetano, 99 Mich. L. Rev. 491, 513 (2000); See also Frank I. Michelman, Conceptions of Democracy in American Constitutional Argument: Voting Rights, 41 FLA. L. REV. 443, 451 (1989) (explaining that the experience of participation in politics is valued "as a process of formation or field of exertion of self or community" through which "persons or communities (or both, reciprocally) forge identities.").

${ }^{13}$ Note that the importance of political liberties may be attributable, in part, to the fact that courts afford the public lawmaking process much more discretion in regulating economic liberties than in regulating political liberties, such as an equally weighted vote and freedom of speech. Compare Nollan v. California Coastal Comm'n, 483 U.S. 825, 834 \& n.3 (1987) (explaining that economic regulations satisfy substantive due process if they are rationally related to a legitimate state interest) with Reynolds $v$. Sims, 377 U.S. 533, 562 (1964) ("[A]ny alleged infringement of the right of citizens to vote must be carefully and meticulously scrutinized."); Boos v. Barry, 485 U.S. 312, 321 (1988) (holding that content-based restrictions on political speech must be subjected to the most exacting scrutiny). See also Kathleen M. Sullivan, Free Speech and Unfree Markets, 42 UCLA L. REV. 949, 950 (1995) ("Modern constitutional law . . . treats speech as presumptively immune from regulation that is broadly permitted in the economic sphere."); Roy A. Schotland, Proposals for Campaign Finance Reform: An Article Dedicated to Being Less Dull Than Its Title, 21 CAP. U. L. REV. 429, 435 (1992) (observing that a commitment to political equality coexists with acceptance of economic inequality).
} 


\title{
I. RACE THEORY AND PROPERTY
}

Race theorists have asserted that formal equality in civil and political rights is insufficient to alter racial hierarchy. "Economic and social rights" the argument goes, should be viewed "as part of the tapestry of rights that are fundamental, in addition to civil and political rights." 15 The theorists claim that racial history and context should play a significant role in legal analysis generally. ${ }^{16}$ Legal decisionmakers create and interpret laws, the race theorists argue, based on the false assumption that the settled distribution of property is "a legitimate and natural baseline, $" 17$ and thereby mask the effects of past discriminatory policies that benefited whites. ${ }^{18}$

\section{For example, laws and policies that allowed confiscation of land from Native Americans ${ }^{19}$ and Mexican Americans, ${ }^{20}$ promoted enslavement of African Americans, ${ }^{21}$ and prohibited}

\begin{abstract}
14 See Kimberle Williams Crenshaw, Race, Reform, and Retrenchment, 101 HaRV. L. ReV. 1331, 1383 (1988) ("Yet the attainment of formal equality is not the end of the story. Racial hierarchy cannot be cured by the move to facial race-neutrality in the laws that structure the economic, political, and social lives of Black people."). (The removal of formal barriers, although symbolically significant to all and materially significant to some, will do little to alter the hierarchical relationship between Blacks and whites until the way in which white race consciousness perpetuates norms that legitimate Black subordination is revealed. ... [U]ntil the distinct racial nature of class ideology is itself revealed and debunked, nothing can be done about the underlying structural problems that account for the disparities.").

${ }^{15}$ Berta Esperanza Hernandez-Truyol \& Shelbi D. Day, Wealth, Inequality and Human Rights: A Formula for Reform, 34 IND. L. REv. 1213, 1233 (2001). See also Derrick Bell, Property Rights in Whiteness-Their Legal Legacy, Their Economic Costs, in CRiticAl RACE THEORY: The CutTING EDGE 75, 81 (Richard Delgado ed., 1995) ("[T] this country is no substitute for the economic justice that has been so long denied."); Derrick A. Bell, Racism: A Prophecy for the Year 2000, 42 RUTGERS L. REV. 93, 106 (1989) ("The ultimate challenge for all progressives, black and white, is to broaden the Constitution's protections to include economic rights. Recognition of entitlement to basic needs-jobs, housing, food, health care, education and security — as essential property rights of all individuals is the fundamental issue."). The economic rights versus political rights debate has been foundational in race literature. See Address by Booker T. Washington, Opening of the Cotton States' Exposition in Atlanta, Ga., September, 1895, in Selected Speeches of Booker T. WASHINGTON $32-36$ (E. Washington ed. 1932) (urging blacks to aim for economic prosperity, and to forego demands for civil rights and sufferage); W.E.B. DuBois, The Souls of Black Folk 36-51 (Penguin, 1989) (originally published 1903) (criticizing Washington's advocacy of "submission and silence as to civil and political rights."); Robert E. Suggs, Bringing Small Business Development to Urban Neighborhoods, 30 HARV. C.R.-C.L. L. REV. 487, 487 n.1 (observing that although Booker T. Washington "established the National Negro Business League in 1900 for the purpose of promoting commercial achievement that would pave the way to economic independence . . . the leadership that won the civil rights victories of the 1960 s . . descended from DuBois"). See Kimberle Williams Crenshaw, Race, Reform, and Retrenchment, 101 HARV. L. REV. 1331, 1383 (1988) ("Yet the attainment of formal equality is not the end of the story. Racial hierarchy cannot be cured by the move to facial race-neutrality in the laws that structure the economic, political, and social lives of Black people.”).
\end{abstract}

${ }^{16}$ See, e.g., Introduction to CRITICAL RACE THEORY: Key WritingS THAT Formed THE Movement xiii, xxiv (Kimberle Crenshaw, Neil Gotanda, Gary Peller, \& Kendall Thomas eds., 1995) ("The debate that ensued in light of this different orientation engendered an important [Critical Race Theory] theme: the absolute centrality of history and context in any attempt to theorize the relationship between race and legal discourse."); Richard Delgado, When a Story is Just a Story: Does Voice Really Matter?, 76 VA. L. REV. 95, 95 n.1 (1990) (identifying "a more contextualized treatment of doctrine" as one theme of critical race theory); Alan David Freeman, Legitimizing Racial Discrimination Through Antidiscrimination Law: A Critical Review of Supreme Court Doctrine, 62 MinN. L. REV. 1049, 1053-54 (1978) ("The perpetrator perspective presupposes a world composed of atomistic individuals whose actions are outside of and apart from the social fabric and without historical continuity.").

${ }^{17}$ Cheryl I. Harris, Whiteness as Property, 106 HARV. L. REV. 1707, 1713-14 (1993) (“After legalized segregation was overturned, whiteness as property evolved into a more modern form through the law's ratification of the settled expectations of relative white privilege as a legitimate and natural baseline.").

${ }^{18}$ Although this Article focuses on past state-sponsored discrimination, which most commentators acknowledge and condemn, many race theorists also focus on present discrimination sponsored by the state and discrimination practiced by private actors. See, e.g., John O. Calmore, Race/ism Lost and Found: The Fair Housing Act at Thirty, 52 U. MiAMI L. REV. 1067 (1998) (asserting that contemporary racism frustrates "the ability of fair housing to render a more inclusive and open society.").

${ }^{19}$ See Joseph W. Singer, The Continuing Conquest: American Indian Nations, Property Law, and Gunsmoke, 1 RECONSTRUCTION 97, 102 (1991) ("[P]roperty and sovereignty in the United States have a racial basis. The land was taken by force by white people from peoples of color thought by the conquerors to be racially inferior."). 
immigration from non-European countries ${ }^{22}$ triggered racial disparities in control over resources. Policies that mandated segregation in education, employment, housing, and business exacerbated these disparities. $^{23}$ Even after courts invalidated facially discriminatory laws, structural phenomena such as intergenerational transfers of wealth ${ }^{24}$ and depressed housing values in minority neighborhoods ${ }^{25}$ have carried forward racial disparities in control over resources.

Current legal doctrines protect expectations over distributions of resources that have been shaped by past discrimination. They thus reinforce and "reproduce subordination in the present." ${ }^{26}$ Such subordination manifests itself in the form of racial disparities in wealth, income, education, unemployment, mortality rates, incarceration rates, and other socioeconomic indicators. $^{27}$

\footnotetext{
${ }^{20}$ See generally Frank D. BeAn \& Marta Tienda, The Hispanic Population of the United States 17-22 (1987) (discussing the oppression of Mexican American landowners by Anglo settlers after the Mexican-American War); CHARLES F. MARDEN ET AL., MinORITIES IN AMERICAN SOCIETy 135, 142, 152, 259-91 (1992) (discussing Mexican American immigration and dominance by Anglo settlers); MARTin N. MARGER, RACE AND ETHNiC RELATIONS 285-90 (2000) (noting that Mexicans' property was taken "through official and unofficial force and fraud").

${ }^{21}$ See Derrick A. Bell, Racism: A Prophecy for the Year 2000, 42 RutGers L. REV. 93,94 (1989) (“The involuntary servitude of black rights to white property interests is the basic explanation for the slavery of the past and the continuing subordinate status of black people today."); Randall Robinson, The DeBt: What AmERicA Owes to Blacks 107-08 (2000) ("[White America] must own up to slavery and acknowledge its debt to slavery's contemporary victims.").
}

${ }^{22}$ See Kevin R. Johnson, Race, the Immigration Laws, and Domestic Race Relations: A "Magic Mirror" into the Heart of Darkness, 73 IND. L.J. 1111 (1998) (analyzing the relationship between the history of racial discrimination in immigration laws and the civil rights of racial minorities in the United States).

${ }^{23}$ See John O. Calmore, Spatial Equality and the Kerner Commission Report: A Back-to-the-Future Essay, 71 N.C. L. REV. 1487, 1489 (1993) ("The harms associated with spatial inequality [in housing] and diminished opportunity now plaguing so much of black America are primarily the result of past discrimination by state and private actors who often operated in tandem."); Robert Westley, Many Billions Gone: Is It Time to Reconsider the Case for Black Reparations? 40 B.C. L. REV. 429,441 (1998) (asserting that by 1950, when "the Federal Housing Authority discontinued its open policy of subsidizing mortgages on real estate subject to racially restrictive covenants . . . thousands of Black families had already missed out on millions of dollars in wealth through equity accumulation, while whites benefited handsomely from discriminatory federal housing subsidies"); Charles R. Lawrence III, Two Views of the River: A Critique of the Liberal Defense of Affirmative Action, 101 COLUM. L. REV. 928, 951 (2001) ("Critical race theory focuses on the persistence of conditions created by and traditionally associated with racist practice. Racism as traditionally practiced led to discriminatory exclusions from employment, from 'white' neighborhoods, from politics, from government contracts, and from universities like Texas, Michigan, and Berkeley.").

${ }^{24}$ See Dalton Conley, Being Black, Living in the Red: Race, Wealth and Social Policy in America 42-53 (1999) (arguing that many racial inequities result from the disparities in accumulated family wealth). While assets conveyed at death are important and perhaps the most obvious way that people pass on wealth, wealth also flows from other types of intergenerational transfers, such as the "education, experiences, friendships, and contacts" a child obtains from parents. MELVIN L. OLIVER AND Thomas M. Shapiro, Black Wealth / White Wealth: A New Perspective on Racial Inequality 152 (1995).

${ }^{25}$ See Richard Banks, Nondiscriminatory Perpetuation of Racial Subordination, 76 B.U. L. REV. 669, 689-90 (1996) (reviewing Melvin L. Oliver and Thomas M. Shapiro, Black Wealth / White Wealth: A New Perspective on Racial IneQuality (1995)); Richard Thompson Ford, The Boundaries of Race: Political Geography In Legal Analysis, 107 HARV. L. REV. 1843, 1848 (1994) (citing Charles Abrams, Forbidden NeIGHBors: A Study OF PreJudice IN Housing 234-35 (1955)); see also Richard Delgado, Rodrigo's Twelfth Chronicle: The Problem of the Shanty, 85 GeO. L.J. 667 (1997) (attributing the poor conditions of the colonias shantytowns in Texas to racism).

${ }^{26}$ Cheryl I. Harris, Whiteness as Property, 106 HARV. L. REV. 1707, 1714 (1993) ("Through this entangled relationship between race and property, historical forms of domination have evolved to reproduce subordination in the present."); $c f$. Kimberle Williams Crenshaw, Race, Reform, and Retrenchment, 101 HARV. L. REV. 1331, 1378-79 (1988) ("Yet the attainment of formal equality is not the end of the story. Racial hierarchy cannot be cured by the move to facial race-neutrality in the laws that structure the economic, political, and social lives of Black people.").

${ }^{27}$ See Randall Robinson, The DEBT: WHAT AMERICA OWES TO BlACKS 59-80 (2000) (focusing on harms of past discrimination, including high infant mortality, low income, high unemployment, substandard education, and high morbidity); John O. Calmore, Spatial Equality and the Kerner Commission Report: A Back-to-the-Future Essay, 71 N.C. L. Rev. 1487, 1489 (1993) ("Spatial inequality's harms are reflected in persistent segregative disadvantage in education, employment, security, and 
Consequently, theorists argue, race-conscious policies such as affirmative action depart from the false neutrality of the status quo, ${ }^{28}$ and are not unfairly discriminatory. ${ }^{29}$ Theorists also use historical discrimination to justify reparations ${ }^{30}$ and other legal changes that would improve the socioeconomic condition of people of color. ${ }^{31}$

In setting forth these important socioeconomic insights, race theorists have necessarily moved beyond an exclusive focus upon civil and political inequalities. But in making this move, they need not - indeed, must not - abandon the language of political rights altogether. The

residence.”); see also Richard America, Paying the Social Debt: What White America Owes Black America 19 (1993) (discussing various models for calculating the debt of past discrimination and estimating that the figure may be between five and ten trillion dollars); Anthony E. Cook, King and the Beloved Community: A Communitarian Defense of Black Reparations, 68 GeO. WASH. L. REV. 959, 1011 (2000) ("In the case of African-Americans, some economists have calculated the debt for the unpaid wages of slavery plus accumulated interest to be over four trillion dollars.").

${ }^{28}$ Cf. Cheryl I. Harris, Whiteness as Property, 106 HARV. L. REV. 1707, 1782 (1993) ("The focus on innocent whites changes the affirmative action inquiry from one of rectifying the harm to Blacks to invoking legal protection for the rights of whites who are innocent of discriminatory acts, although they have benefitted from prior discrimination.").

${ }^{29}$ See Charles R. Lawrence III, Two Views of the River: A Critique of the Liberal Defense of Affirmative Action, 101 CoLuM. L. REV. 928, 931 (2001) (arguing that "more radical substantive defenses" for affirmative action include "the need to remedy past discrimination"); Donald P. Judges, The Constitution and Economically Disadvantaged, Bayonets for the Wounded: Constitutional Paradigms and Disadvantaged Neighborhoods, 19 HASTINGS. Const. L.Q 599, 640 (1992) ("[W]hite males" claims of innocence and unfair treatment rest on dehistoricized premises. . . [T] he notion of equality of opportunity is unintelligible unless it takes into account the disadvantages historically inflicted on minorities and women. Affirmative action . . . merely equalizes the unfair advantage society has given white males at every turn."); Richard Delgado \& Jean Stefanic, California's Racial History and Constitutional Rationales for Race-Conscious Decision-Making in Higher Education, 47 UCLA L. REV. 1521, 1529-30 (2000) (reviewing racial history in California to provide specific and particularized evidence that affirmative action as a needed to remedy past discrimination); Richard Delgado, Why Universities Are Morally Obligated to Strive for Diversity: Restoring the Remedial Rationale for Affirmative Action, 68 U. COLO. L. REv. 1165, 1166 (1997) ("I propose that we resume work on a second basis for affirmative action, namely retributive or remedial justice. This . . approach. . would root affirmative action on ... redress for past discrimination.").

${ }^{30}$ See, e.g., Randall Robinson, The Debt: What America Owes to Blacks 107-08 (2000); W. Burlette Carter, True Reparations, 68 Geo. Wash. L. Rev. 1021, 1022 (2000); Anthony E. Cook, King and the Beloved Community: A Communitarian Defense of Black Reparations, 68 Geo. WASH. L. ReV. 971, 1011 (2000); Mari J. Matsuda, Looking to the Bottom: Critical Legal Studies and Reparations, 22 HARV. C.R.-C.L. L. REV. 323, 381 (1987); Robert Westley, Many Billions Gone: Is It Time to Reconsider the Case for Black Reparations? 40 B.C. L. REV. 429, 438 (1998); Keith Aoki, Space Invaders: Critical Geography, The 'Third World' In International Law and Critical Race Theory, 45 VILL. L. REV 913, 932 (2000); Tuneen E. Chisolm, Sweep Around Your Own Front Door: Examining the Argument for Legislative African American Reparations, 147 U. PA. L. REV. 677, 700-02 (1999); Vincene Verdun, If The Shoe Fits, Wear It: An Analysis of Reparations to African Americans, 67 Tul. L. REv. 597, 664 (1993); Adrienne D. Davis, The Case for United States Reparations to African Americans, 7 Hum. RTS. BR. 3, 3 (2000); Donald Aquinas Lancaster, Jr., The Alchemy and Legacy of the United States of America's Sanction of Slavery and Segregation: A Property Law and Equitable Remedy Analysis of African American Reparations, 43 How. L.J. 171, 211-12 (2000); Kevin Hopkins, Forgive U.S. Our Debts? Righting the Wrongs of Slavery, 89 GEO. L.J. 2531(2001).

${ }^{31}$ See, e.g., John O. Calmore, Spatial Equality and the Kerner Commission Report: A Back-to-the-Future Essay, 71 N.C. L. REV. 1487, 1512-16 (1993) (suggesting a number of litigation remedies and national housing policies to remedy housing discrimination); William E. Forbath \& Gerald Torres, Merit and Diversity After Hopwood, 10 STAN. L. \& POL'Y REV. 185, (1999) (supporting plan that uses "the history of segregation to promote diversity" by entitling "the top 10 percent of the graduating class of each accredited high school in Texas to attend the University of Texas (UT) at Austin”); Mark J. Wolff, Sex, Race and Age: Double Discrimination in Torts and Taxes, 78 WASH. U. L.Q. 1341, 1438 (2000) (suggesting tax law reform that would omit awards of backpay and emotional distress damages received from Title VII claims from taxable income); Rene Bowser, Racial Profiling in Health Care: An Institutional Analysis of Medical Treatment Disparities, 7 MiCH. J. RACE \& L. 79, 132-33 (2001) (suggesting that the law require health care providers who receive funding from the U.S. Department of Health and Human Services to report data on medical treatment by race and ethnicity in order to address issues of racial disparities in medical research and treatment). 
political function of property, as discussed below, reveals that economic liberties and political liberties are closely interrelated.

\title{
II. The Political FunCtion OF PROPERTy
}

While the concept of property serves a variety of functions related to general welfare, productivity, and development, property also serves a political function. ${ }^{32}$ In Buckley v. Valeo, for example, the U.S. Supreme Court accorded heightened protection to an owner's right to use and convey resources to engage in political expression and association. ${ }^{33}$

As theorists have long recognized, property is not a set of "things." It is a cultural and legal creation that, like a bundle of sticks, encompasses various entitlements to control resources. ${ }^{34}$ These entitlements often include the privilege to use resources, the right to prevent others from using the resources without consent, and the power to transfer resources. ${ }^{35}$ Classical liberal theorists conceptualize property as embodying an owner's absolute ability to control a particular resource to the exclusion of the rights of others. ${ }^{36}$ Modern theorists, however, recognize that an owner's entitlements are not always absolute. ${ }^{37}$ Various federal, state, and local legal directives

\begin{abstract}
${ }^{32} C f$. Gregory S. Alexander, Commodity \& Propriety: Competing Visions of Property in American Legal Thought, 1776-1970 2 (asserting that the proprietarian conception of property is committed to the idea that "the core purpose of property is ... to fulfill some prior normative vision of how society and the polity that governs it should be structured."); C. Edwin Baker, Property and its Relation to Constitutionally Protected Liberty, 134 U. PA. L. REV. 741, 744 (1986) ("People rely on, consume, or transform resources in many of their self-expressive, developmental, productive, and survival activities . . .."); $C f$. Frank I. Michelman, Process and Property in Constitutional Theory, 30 CleV. ST. L. Rev. 577, 578 (1982) (asserting that "the constitutional right to property is well understandable as one of the preconditions of a fair democratic system for the determination of the principles of social ordering through public decision."); Frank I. Michelman, Mr. Justice Brennan: A Property Teacher's Appreciation, 15 HARV. C.R.-C.L. L. REV. 294, 304 (1980) (asserting that property is "an essential component of individual comptence in social and political life" and necessary for "self-determination and self-expression").
\end{abstract}

${ }^{33} 424$ U.S. 1 (1976). One might argue that Buckley v. Valeo focuses on expression, rather than property. Ownership of property, however, is the operative factor in determining whether courts will protect an actor's use of property for political purposes. A non-owner does not receive judicial protection from the enforcement of legal restrictions that prevent the non-owner from using another's property to promote the non-owner's views. See Lloyd Corp., Ltd. v. Tanner, 407 U.S. 551, 567-68 (1972) (“Although ... the courts properly have shown a special solicitude for the guarantees of the First Amendment, this Court has never held that a trespasser or an uninvited guest may exercise general rights of free speech on property privately owned. . . .”). But see New Jersey Coalition Against War in the Middle East v. J.M.B. Realty Corp., 650 A.2d 757, 760-62 (N.J. 1994) (finding a right of access for uninvited speakers to distribute leaflets at privately owned malls under the New Jersey constitution, reasoning that the leafleters' expressive rights outweigh any interference with the mall owners' property rights, and finding that such access is necessary for speakers without resources to spend on mass communication).

${ }^{34}$ See Stephen R. MunZer, A Theory Of Property 16-17(1990) (acknowledging the "sophisticated conception" of property as a "bundle of "sticks"" or a set of "legal relations ... among persons or other entities with respect to things").

${ }^{35}$ See Joseph William Singer, Property Law: Rules, Policies and Practices 4-5 (1997) (“The most important [property] rights include: Liberty to use . . . Right to exclude . . . Power to transfer . . . Power to devise or bequeath . . . Immunity from damage ... Immunity from ... expropriation.”).

${ }^{36}$ See, e.g., Sir William Blackstone, 2 Commentaries on the Law of England 2 (George Chase ed., Banks \& Company 1910) (1766) (describing the right of property as "that sole and despotic dominion which one man claims and exercises over the external things of the world, in total exclusion of the right of any other individual in the universe.").

${ }^{37}$ See Thomas Grey, The Disintegration of Property, in NomOs XXII: ProperTY 69, 69 (J. Roland Pennock \& John W. Chapman eds., 1980) (recognizing the modern view of property as a bundle of rights); JOSEPH William SingER, PROPERTY LAW: RULES, POLICIES AND PRACTICES 4 (1997) ("No property right is absolute; each right that accompanies ownershipof property is limited by the rights of others."). But see Madhavi Sunder, Authorship and Autonomy as Rites of Exclusion: The Intellectual Propertization of Free Speech in Hurley v. Irish-American Gay, Lesbian and Bisexual Group of Boston, 49 STAN. L. REV. 143, 151 (1996) 
that arise from constitutions, statutes, regulations, and judicial opinions qualify the extent to which society will respect of an individual's right to use, convey, or otherwise control a particular resource for a particular function. ${ }^{38}$

In Buckley, the U.S. Supreme Court extended to individuals expansive rights to use, control, and convey financial resources to communicate political messages. ${ }^{39}$ Buckley involved a challenge to expenditure and contribution limitations contained in the Federal Election Campaign Act Amendments of 1974 (the "1974 Act"). ${ }^{40}$ Invoking the First Amendment, the Court invalidated an array of expenditure limitations, including provisions that limited the amounts that could be spent by a campaign, by a candidate from her personal funds, and by a noncandidate on behalf of a candidate. ${ }^{41}$ In contrast, the Court upheld contribution limits,

("While the post-Realist conception of real property is no longer built on a regime of absolute rights in these entitlements, the bundle of sticks conception of property has failed to infiltrate the absolutist regime governed by intellectual property laws.").

\begin{abstract}
${ }^{38}$ See Jeremy Bentham, The Theory of Legislation 111-13 (C.K. Ogden ed. \& Richard Hildreth trans., 1931) ([P]roperty and law are born together, and die together. Before laws were made there was no property; take away laws, and property ceases."); C. Edwin Baker, Property and its Relation to Constitutionally Protected Liberty, 134 U. PA. L. REV. 741, 744 (1986) ("Property rules determine when the community will recognize a person's assertion of a right to use a particular resource for these purposes."); Margaret Jane Radin, The Liberal Conception of Property: Cross Currents in the Jurisprudence of Takings, 88 CoLUM. L. REV. 1667, 1678 (1988) ("Every regulation of any portion of an owner's 'bundle of sticks,' is a taking of the whole of that particular portion considered separately. Price regulations 'take' that particular servitude curtailing free alienability, building restrictions 'take' a particular negative easement curtailing control over development, and so on.”).
\end{abstract}

Just as property commentators have described the rights associated with property as arising from legal directives, democracy scholars have noted that democracy does not consist simply of individual citizens exercising political liberties in a neutral, prepolitical world; rather, democracy is also shaped by institutional and legal structures that determine the boundaries of possible political outcomes. See Samuel Issacharoff, Pamela S. Karlan \& Richard H. Pildes, The Law of Democracy: Legal STRUCtURe OF THE Political Process 1-2 (1998) (stating that "[t]he kind of democratic politics we have is always and inevitably itself a product of institutional forms and legal structures" which "limit and define the decisions available through democratic politics itself"). A racial analysis reveals that laws governing property and laws governing democracy are not mutually exclusive, but overlap to shape both the meaning of property and the meaning of democracy. The rules and doctrines that govern democracy, such as the Court's invalidation of expenditure limits in Buckley, shape the contours of property rights. At the same time, the rules and doctrines that govern property, such as past discriminatory allocation rules, shape the contours of democracy.

${ }^{39}$ See Daniel A. Farber, Property and Free Speech, 93 Nw. U.L. REV. 1239, 1239 (1999) ("Property, as first-year law students learn, is like a 'bundle of sticks,' composed of various powers, rights, and immunities. Among those sticks is the capacity to use property for communicative purposes - either directly, as when we post a sign on our front lawn, or indirectly, as when we use money to pay for a newspaper ad."). In the first 150 years of the existence of the United States, property served other political functions. Property was seen as the basis for liberty, and thus property rights were less prone to political reallocation. Further, many jurisdictions conditioned the franchise on property ownership because of the assumption that property holders could best

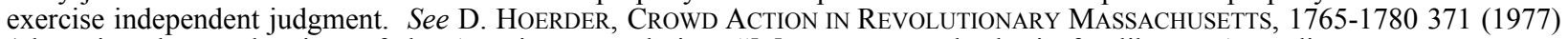
(observing that at the time of the American Revolution, "[p]roperty was the basis for liberty. According to contemporary ideology, it made men independent from the influence of others."); Daniel R. Ortiz, The Democratic Paradox of Campaign Finance Reform, 50 STAN. L. REV. 893, 907 (1998) ("Originally . . . property qualifications were thought to promote a vital goal: ensuring that voters had a stake in political matters and exercised independent political judgment.”).

${ }^{40}$ See Federal Election Campaign Act Amendments of 1974, Pub. L. No. 93-443, 88 Stat. 1263 (repealed 1976).

${ }^{41}$ The expenditure limitation provisions were as follows: (1) a $\$ 1,000$ annual ceiling on independent expenditures (expenditures by a noncandidate to promote the election or defeat of a clearly identified candidate), see 18 U.S.C. § 608(e)(1) (Supp. IV 1974) (repealed 1976), (2) an annual ceiling on campaign expenditures from a candidate's personal or family funds, see 18 U.S.C. § 608(a)(1) (Supp. IV 1974) (repealed 1976), and (3) a variable ceiling on total campaign expenditures from all sources, see 18 U.S.C. § 608(c) (Supp. IV 1974) (repealed 1976). This Article is limited to a discussion of the portion of the 1974 Act concerning campaign contributions and expenditures. Buckley also invalidated regulatory provisions providing for appointments to the Federal Election Commission by congressional leaders (based on the separation of powers doctrine), see Buckley v. Valeo, 424 U.S. 1, 138-41 (1976), and upheld disclosure provisions, see Buckley v. Valeo, 424 U.S. 1, 60-84 (1976), and public financing provisions, see Buckley v. Valeo, 424 U.S. 1, 85-109 (1976). For important literature providing additional information on Buckley and the campaign finance dilemma generally, see CAMPAIGN FINANCE REFORM: A SOURCEBOOK (Anthony Corrado, Thomas E. Mann, Daniel R. Ortiz, Trevor Potter \& Frank Sorauf eds., 1997) (providing a broad overview of campaign finance 
including a provision that prohibited individuals from contributing more than $\$ 1,000$ to a candidate for federal office. ${ }^{42}$

The Court deemed individuals to have an absolute right to exercise proprietary liberties ${ }^{43}$ in spending resources to produce political communication. ${ }^{44}$ In explaining its holding, the Court emphasized the essential function of property in exercising expressive and political liberties, stating that:

[V]irtually every means of communicating ideas in today's mass society requires the expenditure of money. The distribution of the humblest handbill or leaflet entails printing, paper, and circulation costs. Speeches and rallies generally necessitate hiring a hall and publicizing the event. The electorate's increasing dependence on television, radio, and other mass media for news and information has made these expensive modes of communication indispensable instruments of effective political speech. ${ }^{45}$

The Court reasoned that spending money is so closely connected to effective political communication that expenditure limits restrict the use "of virtually every means of communicating information." 46 Therefore, the Court concluded, any restriction on expenditures impermissibly restricted political communication.

Although the Court did not extend to individuals such extensive rights to contribute financial resources to campaigns, the Court prohibited excessive legislative restrictions on the exercise of these liberties. The Court upheld the $\$ 1,000$ contribution limits, reasoning that contributions were not as closely related to expression as expenditures ${ }^{47}$ and that the contribution limits were

controversies, regulations, opinions, and reform proposals); DANIEL H. LOWENSTEIN \& RiCHARD L. HASEN, ELECTION LAW CASES AND MATERIALS 747-82, 923-62 (2d. ed. 2001) (covering the Court's contribution and expenditure limit holdings); E.

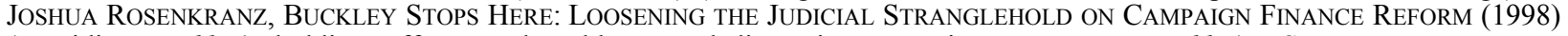
(providing Buckley's holding, effects, and problems, and discussing strategies to overturn Buckley); SAMUEL ISSACHAROFF, Pamela S. Karlan \& Richard H. Pildes, The Law of Democracy: Legal Structure of the Political Process $449-545$ (2d ed. 2001) (covering major campaign finance cases and issues).

${ }^{42}$ With regard to contributions, the 1974 Act prohibited an individual from giving more than $\$ 1,000$ to a particular candidate per election, see 18 U.S.C. $\S 608(b)(1)$ (Supp. IV 1974) (modified 1976, recodified at 2 U.S.C. $\S 441 a(a)(1)(A)$ ), and limited an individual's overall contributions to $\$ 25,000$ per year, see 18 U.S.C. $\$ 608$ (b)(3) (Supp. IV 1974) (modified 1976, recodified at 2 U.S.C. $\S 441 \mathrm{a}(\mathrm{a})(3))$.

${ }^{43}$ Economic liberties, or freedom in "choices and modes of productive activity and investment," are sometimes distinguished from proprietary liberties, or freedom in "retention, use, and disposition of lawfully obtained holdings of wealth." Frank I. Michelman, Liberties, Fair Values, and Constitutional Method, 59 U. CHI. REV. 91, 95 (1992). This Article, however, uses these terms interchangeably.

${ }^{44}$ Note, however, the political spending in coordination with a candidate is treated as an in-kind contribution and is subject to contribution restrictions. See Colorado Republican Federal Campaign Committee v. Federal Election Com'n, 518 U.S. 604, 618, (1996); 2 U.S.C. $§ 441 \mathrm{a}(\mathrm{a})(7)(B)(\mathrm{i})$.

${ }^{45}$ Buckley v. Valeo, 424 U.S. 1, 19 (1976). The Court suggested that money is needed for political communication just as gas is needed to drive a car. See Buckley v. Valeo, 424 U.S. 1, 18 n.18 (1976) ("Being free to engage in unlimited political expression subject to a ceiling on expenditures is like being free to drive an automobile as far and as often as one desires on a single tank of gasoline.").

${ }^{46}$ Buckley v. Valeo, 424 U.S. 1, 18 n.17 (1976).

${ }^{47}$ See Buckley v. Valeo, 424 U.S. 1, 21 (1976) ("A limitation on the amount of money a person may give to a candidate or campaign organization thus involves little direct restraint on his political communication, for it permits the symbolic expression of support evidenced by a contribution but does not in any way infringe the contributor's freedom to discuss candidates and issues. While contributions may result in political expression if spent by a candidate or an association to present views to the 
needed to prevent corruption and the appearance of corruption. ${ }^{48}$ Despite this holding, the Court noted that contribution restrictions must not be too extensive because of "the important role of contributions in financing political campaigns." 49 The Court observed that effective campaigning relies on broadcast and newspaper advertisements, mass mailings, and polling operations, all of which are often made possible by contributions. ${ }^{50}$ With regard to associational interests, contributions enable "like-minded persons to pool their resources in furtherance of common political goals." $" 51$ Because contributions allow candidates and political committees to amass resources necessary for political dialogue, the Court determined that contribution limits must be sufficiently high so as not to interfere with the ability of candidates to engage in effective advocacy. ${ }^{52}$

The Court extended enhanced protection to the exercise of property rights to make expenditures and contributions because of the unique values associated with political expression and association. According to the Court, these property rights were necessary to promote the "the widest possible dissemination of information from diverse and antagonistic sources." 53 The Court stated that such an exercise of property rights promotes the "interchange of ideas for the bringing about of political and social changes desired by the people." 54 The exercise of such rights ensures that "the people-individually as citizens and candidates and collectively as associations and political committees- ... retain control over the quantity and range of debate on public issues in a political campaign."

voters, the transformation of contributions into political debate involves speech by someone other than the contributor."); Buckley v. Valeo, 424 U.S. 1, 23 (1976) ("In sum, although the Act's contribution and expenditure limitations both implicate fundamental First Amendment interests, its expenditure ceilings impose significantly more severe restrictions on protected freedoms of political expression and association than do its limitations on financial contributions.”).

${ }^{48}$ See Buckley v. Valeo, 424 U.S. 1, $26-29$ (1976); Buckley v. Valeo, 424 U.S. 1, 23 (1976) ("In sum, although the Act's contribution and expenditure limitations both implicate fundamental First Amendment interests, its expenditure ceilings impose significantly more severe restrictions on protected freedoms of political expression and association than do its limitations on financial contributions.").

${ }^{49}$ Buckley v. Valeo, 424 U.S. 1, 21 (1976).

${ }^{50}$ See Buckley v. Valeo, 424 U.S. 1, 26 (1976) (“Under a system of private financing of elections, a candidate lacking immense personal or family wealth must depend on financial contributions from others to provide the resources necessary to conduct a successful campaign. The increasing importance of the communications media and sophisticated mass-mailing and polling operations to effective campaigning make the raising of large sums of money an ever more essential ingredient of an effective candidacy.").

${ }^{51}$ Buckley v. Valeo, 424 U.S. 1, 22 (1976).

${ }^{52}$ See also Nixon v. Shrink Mo. Gov't PAC, 528 U.S. 377, 397 (2000) (concluding that a contribution limit is unconstitutional when it is so low as to "impede the ability of candidates to "amass the resources necessary for effective advocacy" and "render political association ineffective, drive the sound of a candidate's voice below the level of notice, and render contributions pointless") (quoting Buckley v. Valeo, 424 U.S. 1, 21 (1976)). In Nixon v. Shrink, the Court explicitly reviewed contribution limits using a standard of scrutiny that was more stringent than intermediate scrutiny but "different" from the strict scrutiny applied to expenditure limits. See Nixon v. Shrink Mo. Gov't PAC, 528 U.S. 377, 385-87 (2000). But see Richard L. Hasen, Shrink Missouri, Campaign Finance, and "The Thing that Wouldn't Leave," 17 CONST. COMMENTARY 483, 496-97 (2000) (asserting that Shrink's test to establish that contribution limits are unconstitutionally low "will be exceedingly difficult for challengers to meet" and therefore suggesting that the test functions as a rule).

${ }^{53}$ Buckley v. Valeo, 424 U.S. 1, 49 (1976) (quoting New York Times Co. v. Sullivan, 376 U.S. 254, 266, 269 (1964), quoting Associated Press v. United States, 326 U.S. 1, 20 (1945)).

${ }^{54}$ Buckley v. Valeo, 424 U.S. 1, 14 (1976) (quoting Roth v. United States, 354 U.S. 476, 484 (1957)).

${ }^{55}$ Buckley v. Valeo, 424 U.S. 1, 57 (1976). 


\section{DiscriminAtory AllocAtion RUles LiMit the EXERCiSE OF POLITICAL LiBERTIES}

In drawing an explicit connection between the use of wealth and political liberty, the Court in Buckley made apparent a crucial argument that advances the critical race project. Following the reasoning of Buckley, past discriminatory laws inevitably impair the ability of people of color to exercise rights over economic resources to participate in the political process.

In addition to rules that restrict or protect one's control over her property, allocation rules "structure people's opportunities and incentives to obtain and use resources." ${ }^{, 56}$ Allocation rules are not pre-political, but instead are shaped by culture, history, and politics, ${ }^{57}$ and essentially determine how decisionmaking authority over particular resources is organized and distributed. ${ }^{58}$ Consequently, allocation rules are related to individual exercises of substantive liberty in that they establish "the framework within which liberty exists." 59 Those who have benefited from allocation rules are able to exercise liberties related to property for political purposes, while those who have not benefitted are unable to do so. Thus, allocation rules are inextricably tied to the value of liberty associated with property, and determine the value of one person's liberties relative to those of another. ${ }^{60}$ Allocation rules are no less important to the value of liberty than rules that directly restrict or expand the formal exercise of property rights. ${ }^{61}$

The Court has recognized that biased allocation rules can unfairly disadvantage particular actors in their exercise of political liberties. In contrast to the First Amendment absolutism of Buckley, the Court tolerated expenditure limitations in Austin v. Michigan Chamber of Commerce. $^{62}$ In Austin, the Court upheld a Michigan statute that prohibited corporations from using money from their general treasuries to make contributions or expenditures on behalf of candidates. To the Court, special allocation rules, such as "limited liability, perpetual life, and favorable treatment of the accumulation and distribution of assets,",63 gave corporations "legal

\footnotetext{
${ }^{56}$ C. Edwin Baker, Property and its Relation to Constitutionally Protected Liberty, 134 U. PA. L. REV. 741,766 (1986).

${ }^{57}$ See C. Edwin Baker, Property and its Relation to Constitutionally Protected Liberty, 134 U. PA. L. REV. 741,743 (1986) ("Culture, history, and politics (broadly defined) necessarily determine both the content of the specific property rules accepted in a given society and the resulting property allocations. I will here assume what I think should be obvious: that the notion of a complete set of timeless, natural, or proper property rules is absurd.").
}

${ }^{58}$ See C. Edwin Baker, Property and its Relation to Constitutionally Protected Liberty, 134 U. PA. L. REV. 741, 779-80 (1986) (observing that "'allocation rules,' determine who is entitled to make and carry out any particular decision. They embody the criteria that identify the possessor of a property right, that is, the possessor of decisionmaking authority. ...”).

${ }^{59}$ C. Edwin Baker, Property and its Relation to Constitutionally Protected Liberty, 134 U. PA. L. REV. 741, 780 (1986) ("Because the existence of these types of rules or practices is inevitable, they should not be seen as necessarily inconsistent with all meaningful conceptions of liberty. Rather, they are better seen as establishing the framework within which liberty exists.").

${ }^{60}$ See Frank Michelman, Liberties, Fair Values, and Constitutional Method, 59 U. CHI. L. REV. 91, 99 (1992) ("In a capitalist order, one person's proprietary value (or power) is obviously relative to other people's. A constitutional system of proprietary liberty is, therefore, incomplete without attending to the configurations of the values of various people's proprietary liberties. The question of distribution is endemic in the very idea of a constitutional scheme of proprietary liberty. Thus, it can by no means be said of laws aimed at nothing but property distributions that they are ipso facto antithetical to that idea.").

${ }^{61}$ Cf. JOHN RAwls, A TheORY OF JustiCE 178-79 (Rev. ed. 1999) (explaining that liberties only have value when individuals possess sufficient resources to take advantage of them, and concluding that any theory of political justice must be accompanied by a theory of just economic distribution).

${ }^{62} 494$ U.S. 652 (1990).

${ }^{63}$ Austin v. Michigan Chamber of Commerce, 494 U.S. 652, 658-59 (1990). 
advantages" in amassing wealth. ${ }^{64}$ The Court stated that aggregations of wealth that are "accumulated with the help of the corporate form" 65 can "influence unfairly the outcome of elections." 66 The Court concluded that "the unique state-conferred corporate structure that facilitate[d] the amassing of large treasuries warrants the limit on independent expenditures."67 Some commentators have viewed Austin as an anomaly. ${ }^{68}$ Nonetheless, the case recognizes that allocation rules determine the value of expressive and proprietary liberties and may warrant legislative intervention that reallocates the value of these liberties. ${ }^{69}$

In addition to laws that give special benefits to corporations, allocation rules include past racially discriminatory laws that have shaped the distribution of property, along with laws and practices that have carried racial disparities forward. Because of discriminatory allocation rules, many whites are more able and more likely to exercise liberties related to property for political purposes, while many people of color are less able and less likely to do so. ${ }^{70}$

Studies confirm this insight. Large contributions play a crucial role in funding American politics, ${ }^{71}$ but a disproportionately small number of such contributions come from people of color. Even though people of color comprise approximately $30 \%$ of the nation's population, ${ }^{72}$

${ }^{64}$ See Austin v. Michigan Chamber of Commerce, 494 U.S. 652, 659 (1990) (citing FEC v. Mass. Citizens for Life, Inc., 479 U.S. 238, $258 \mathrm{n} .11$ (1986)) (observing that corporations are "by far the most prominent example of entities that enjoy legal advantages enhancing their ability to accumulate wealth.”).

${ }^{65}$ Austin v. Michigan Chamber of Commerce, 494 U.S. 652, 660 (1990).

${ }^{66}$ See Austin v. Michigan Chamber of Commerce, 494 U.S. 652, 669 (1990).

${ }^{67}$ Austin v. Michigan Chamber of Commerce, 494 U.S. 652, 660 (1990).

${ }^{68}$ See Miriam Cytryn, Defining the Specter of Corruption: Austin v. Michigan Chamber of Commerce, 57 BROOK. L. REV. 903, 904 (1991) ("Notably, this [Austin decision] was the first time that the Supreme Court had found an expenditure restriction constitutional as applied.”).

${ }^{69}$ But see Austin v. Michigan Chamber of Commerce, 494 U.S. 652, 707 (1990) (Kennedy, J., dissenting, joined by O’Connor and Scalia, JJ.) (Asserting that it is a "fallacy that the source of the speaker's funds is somehow relevant to the speaker's right of expression ... "); FCC v. League of Women Voters of California, 468 U.S. 364 (1984) (invalidating a congressionally imposed ban upon editorializing by noncommercial broadcasting stations that receive federal funds, reasoning that under the statute, the station "is barred from using even wholly private funds to finance its editorial activity.").

${ }^{70}$ The failure of minorities to make political contributions is more attributable to a lack of resources than a lack of desire to donate money. See Henry E. Brady, Sidney Verba \& Kay Lehman Schlozman, Race, Ethnicity, and Political Participation, in Classifying By Race 354, 361-62 (Paul E. Peterson, ed. 1995) ("When it comes to time, minority activists are not less active than their white counterparts. ... The situation is different with respect to money. Among contributors, whites - who are, ..., slightly more likely than African Americans and considerably more likely than Latinos to make campaign donations -give substantially more than African Americans or Latinos do when they contribute."); Henry E. Brady, Sidney Verba \& Kay Lehman Schlozman, Beyond SES: A Resource Model of Political Participation, 89 Am. Pol. Sci. Rev. 271, 283 (1995) (“[T]he major determinant of giving money is having money. Years of education also matter, but neither free time nor civic skills affect monetary contributions."). Minority participation is much higher in other forms of political activity that are not so closely related to control over economic resources. For example, even though minorities give only about $1 \%$ of political contributions, they cast 23\% of the votes in the 2000 general presidential election. See Marjorie Connelly, Who Voted: A Portrait of American Politics, 1976-2000, N.Y. Times, Nov. 12, 2000, at WK 4; see also Henry E. Brady, Sidney Verba \& Kay LeHMAn SchlOZMAn, Voice AND EQUALITY 233 (1995) ("When it comes to activity within a campaign, African Americans are more likely to say that they have worked in a campaign but less likely to say that they have given money.").

${ }^{71}$ See Public CAMPAign, Hard FACTS ON HARD MONEY (2001) at www.publicampaign.org/hardfacts/index2.html (indicating that "[i]n the 2000 elections, seven out of ten dollars collected by the federal candidates from individual donors came from donors of $\$ 200$ or more; 44 percent came from donors giving $\$ 1,000$ or more.").

${ }^{72}$ See U.S. Bureau of the Census, Resident Population Estimates of the United States by Sex, Race, and Hispanic Origin: April 1, 1990 to July 1, 1999, with ShORT-Term ProjeCtion to NovemBer 1, 2000, at 1 (2000) [hereinafter Census 
they represent only about $1 \%$ of those who make reportable contributions to federal candidates. ${ }^{73}$ Residents in the average American zip code make federal contributions at three times the rate of residents in zip codes populated predominantly by people of color. ${ }^{74}$ The 41.3 million inhabitants of America's 2492 predominantly nonwhite zip codes collectively gave less money than the 680,000 inhabitants of the twenty-six zip codes with the highest rates of giving. ${ }^{75}$ Even elected officials who represent districts that are populated predominantly by people of color tend to receive most of their campaign money from white contributors. ${ }^{76}$ Thus, the nature of political debate in minority communities "is largely dependent on the behavior of whites."77

While limitations on large contributions and expenditures restrict the liberty of some individuals, discriminatory allocation rules restrict the political liberties of many people of color in contravention of the reasoning of Buckley. Because of the crucial role that money plays in political communication, the rules disadvantage many people of color in "virtually every means of communicating ideas.",78 People of color have less access to "indispensable instruments of effective political speech" ${ }^{, 79}$ such as television, radio, and other mass media outlets. People of color control fewer resources and are thus less able to pool resources with like-minded persons in furtherance of common political goals. Discriminatory allocation rules also hinder fundraising and effective advocacy by those candidates that people of color support. ${ }^{80}$ Such discriminatory allocation rules prevent "the widest possible dissemination of information from diverse and

Population Estimates] (indicating that as of November 1, 2000, African Americans made up 12.8\%, Hispanics 11.9\%, Asian Americans $4.1 \%$, and American Indians, Eskimos, and Aleuts $0.9 \%$ of the population of the United States).

${ }^{73}$ See John Green, Paul Herrnson, Lynda Powell \& Clyde Wilcox, Individual Congressional Campaign Contributors: Wealthy, Conservative and Reform-Minded, Individual Donors and Campaign Finance, JOYCE FOUNDATION, 1998, at 13 (showing that less than $1 \%$ of contributors surveyed identified themselves as people of color, whereas $95 \%$ indicated they are white); see also John A. Clark \& John M. Bruce, Campaign Contributions in Georgia 7 (1994) ("In the 1990 Census, the population of Georgia was reported to be $71 \%$ white and $27 \%$ black. Our pool of respondents [of financial contributors to campaigns] was just over 97\% white, with only about 2\% black."); Richard Whitt, 'Typical' donor no average Georgian, ATLANTA J. \& CONST., Dec. 14, 1994, at C2 ("More than 97 percent of contributors responding to the survey were white and only 2 percent were black. . . . Questionnaires were mailed in August and September to 1,155 contributors, with 357 initial responses.”).

${ }^{74}$ See Public Campaign, The Color of Money: Campaign Contributions and Race 36-37 (1998).

${ }^{75}$ See Public Campaign, The Color of Money: Campaign Contributions and Race 37 (1998). For general information on Public Campaign and an abbreviated version of the study, see http://www.publicampaign.org. Racial disparities in political spending have not been studied as extensively as racial disparities in individual contributions. Recognizing the lack of spending limits, however, it is very possible that the racial disparities in political spending are even greater.

\footnotetext{
${ }^{76}$ See Robert C. Smith, Financing Black Politics: A Study of Congressional Elections, 17 ReV. OF Black POL. ECON. 5 , 24 (1988) (observing that "congressional elections in the black community tend to be financed largely by white dominated PACs and disproportionately by large (probably white) individual contributors . . . ."); RoBERT SingH, THE CONGRESSIONAL BLACK CAuCus: Racial Politics IN THE U.S. CONGRESS 125-26 (1998) ("The funding of black campaigns remains substantially the province of political actors external to black communities. ... Without exception, over every congressional election cycle, CBC members raise more funds from PACs alone than their challengers raise from all sources combined.").

${ }^{77}$ Robert C. Smith, Financing Black Politics: A Study of Congressional Elections, 17 ReV. OF BLACK POL. ECON. 5, 24 (1988).

${ }^{78}$ Buckley v. Valeo, 424 U.S. 1, 18 n.17 (1976).

${ }^{79}$ Buckley v. Valeo, 424 U.S. 1, 19 (1976).

${ }^{80} \mathrm{Cf}$. John Theilmann \& Al Wilhite, Discrimination and Congressional CAmpaign Contributions 78 (1991) (“"[T]here does seem to be a pattern of racial discrimination in the allocation of total campaign contributions. After controlling for attributes such as candidate strength, opposition strength, party affiliation, and the incumbency advantage, black candidates received substantially lower levels of funds than did nonblack candidates. Because the primary determinants of candidates' fundraising abilities are included in the analysis, the differential appears to be racially motivated.").
} 
antagonistic sources" 81 and prevent an "interchange of ideas" that will bring about "political and social changes desired" by many people of color. ${ }^{82}$ The rules thus hinder individual autonomy, self-expression, and self-determination of people of color. ${ }^{83}$

Although this Article focuses on campaign finance to illustrate how past discriminatory allocation rules infringe on the present value of both the economic liberties and the political liberties of people of color, these harms are much broader. Even outside of the campaign finance context, discriminatory allocation rules infringe upon the ability of people of color to exercise political liberties. ${ }^{84}$

First, past discrimination impairs the extent to which people of color spend money to exercise other, related political liberties. For example, on the whole, whites are better positioned to pool their resources and hire a lobbyist or purchase airtime to promote their personal opinions on affirmative action, criminal sentencing, and other general political issues. Such spending on lobbying and "issue advertisements" may significantly impact legislative outcomes. Further, wealthier whites disproportionately own and control major newspapers and television news operations, and thus people of color exercise minimal control over endorsements, editorials, and news reports that discuss candidates and ballot initiatives. Similarly, people of color own and control few book publishing companies, recording companies, movie studios, and other major entities that produce expression. Through a barrage of images related to language, conduct, and values, these entities enjoy significant influence not simply over election results and government policy, but also over the meaning of racial identity (as understood by people of color as well as by whites). ${ }^{85}$ Due to a lack of ownership and other legal relationships that allow for control of

\footnotetext{
${ }^{81}$ Buckley v. Valeo, 424 U.S. 1, 49 (1976), (quoting New York Times Co. v. Sullivan, 376 U.S. 254, 266, 269 (1964), quoting Associated Press v. United States, 326 U.S. 1, 20 (1945).

${ }^{82}$ Buckley v. Valeo, 424 U.S. 1, 14 (1976) (quoting Roth v. United States, 354 U.S. 476, 484 (1957)).
}

\begin{abstract}
${ }^{83}$ While Buckley allows for a more comprehensive understanding of the harms caused by discriminatory laws that have deprived many people of color of resources, the opinion is troubling in the absence of some sort of redistribution that offsets past discriminatory allocation rules. Another way to view this problem, at least in the campaign finance context, involves a focus on not merely the discriminatory allocation rules themselves, but on the decision in Buckley to defer to a distribution of resources shaped by discriminatory allocation rules as a baseline for political participation. The Buckley Court constitutionalizes a right to exercise control over resources for political expression that is parasitic on discriminatory allocation rules that we would today consider unconstitutional. Without some form of redistribution of liberties, Buckley effectively advances the political ideologies of those who have profited from the discriminatory misallocation of property. Indeed, Buckley's additional protection of settled expectations is in itself an allocation rule. The decision multiplies the rights associated with property ownership and expands disparities between those who have benefited from past discriminatory allocation rules and those who have not. Along similar lines, if property is an aspect of social relations between people that focuses on "rights" rather than "things," recognition of the political function of property contribute to a better understanding of how these "rights" shape social relations in the context of a democracy. See generally Spencer A. Overton, But Some Are More Equal: Race, Exclusion, and Campaign Finance, 80 TEX. L. REV. (forthcoming 2002).

${ }^{84}$ Past state-sponsored discrimination also impairs people of color in their ability to use resources to exercise a variety of other liberties, such as those related to counsel, privacy, and religion. Just as past discrimination shapes disparities in campaign contributions and expenditures, it may also contribute to racial disparities in criminal convictions, out-of-wedlock pregnancies, and other social circumstances.

${ }^{85}$ Some race theorists have rejected the near absolute judicial protection of hate speech and other racially demeaning messages, arguing that the power of racist cultural messages should be curtailed in light of context, history, and politics. See, e.g., MARI J. Matsuda, Charles R. Lawrence III, Richard Delgado, and Kimberle Williams Crenshaw, Words that Wound: Critical Race Theory, Assaultive Speech, And the First Amendment (1993); Richard Delgado, Toward a Legal Realist View of the First Amendment, 113 HARV. L. REV. 778, 779 (2000) ("Under the influence of radical feminism and critical race
\end{abstract}


resources used for expression, people of color are hindered in their ability to counter oppressive images effectively in the marketplace of ideas. Further, people of color are less able to demand alternative programming because they do not form a high-end target audience for advertisers. ${ }^{86}$

Second, past discriminatory allocation rules effectively interfere with the opportunity of many people of color to cast a vote. Certain technologies, such as optical scanning machines that more accurately record votes and Internet voting programs that allow individuals to vote from home, may appear to open the process and allow for enhanced participation. Just as individuals who have benefited from discriminatory allocation rules are better equipped to pay poll taxes, own property, ${ }^{87}$ and pass literacy tests, ${ }^{88}$ however, they also may have greater access to optical scanning machines and Internet voting. ${ }^{89}$ Thus, such technologies may skew the distribution of political liberties. ${ }^{90}$ To the extent that incarceration rates correspond with poverty, felon

theory, this last remnant of 1890 s mechanical jurisprudence is beginning to give way to a view of speech that is flexible, policysensitive, and mindful of communication theory, politics, and setting."); Richard Delgado, First Amendment Formalism Is Giving Way to First Amendment Legal Realism, 29 HARV. C.R.-C.L. L. Rev. 169 (1994); Charles R. Lawrence III, If He Hollers Let Him Go: Regulating Racist Speech on Campus, 1990 DuKe L.J. 431 (1990). The problem arises, however, not simply from the images themselves, but also from the inability of people of color to counter derogatory images with more constructive images, which arises in large part from racial disparitiesin wealth.

${ }^{86} \mathrm{Cf}$. Kurt A. Wimmer, The Future of Minority Advocacy Before the FCC: Using Marketplace Rhetoric To Urge Policy Change, 41 FeD. COMM. L.J. 133, 141-42 (1989) ("All viewers are not valued equally by advertisers. [A] large audience may be desirable, prompting programmers to tailor programming to . . . majority interests . . . [A] small, high-income demographic may be desirable, prompting programmers to tailor programming to the young, white audience . . . Under either scenario, minority audiences are disenfranchised.").

${ }^{87}$ See U.S. ConsT. amend. XXIV, $§ 1$ (prohibiting poll taxes as a requirement to vote for federal candidates); Harper v. Virginia Board of Elections, 383 U.S. 663 (1966) (invalidating poll taxes in state elections); Cipriano v. City of Houma, 395 U.S. 701 (1969) (concluding that a Louisiana provision limiting the right to vote on the issuance of revenue bonds to taxpayers violated the Equal Protection Clause); City of Phoenix v. Kolodziejski, 399 U.S. 204 (1970) (invalidating provision excluding nonproperty owners from voting in an election to approve general-obligation bonds); Hill v. Stone, 421 U.S. 289 (1975) (concluding a Texas provision impermissibly disenfranchised otherwise qualified voters solely because they had not rendered their property for taxation). But cf. Buckley v. Valeo, 424 U.S. 1, 49 n.55 (1976) (rejecting the argument that Harper allows Congress to restrict political expenditures); Salyer Land Co. v. Tulare Lake Basin Water Storage Dist., 410 U.S. 719, 726-30 (1973) (concluding that property-based scheme for electing governing board of water reclamation district does not violate equal protection); Ball v. James, 451 U.S. 355 (1981) (concluding state could rationally limit voting in a water district election to landowners and that each vote could be weighted respective to the amount of land each voter owned).

${ }^{88}$ Literacy, which is often related to wealth, cannot be a requirement for political participation pursuant to the Voting Rights Act. See South Carolina v. Katzenbach, 383 U.S. 301, 334 (1966) ("The [Voting Rights] Act suspends literacy tests and similar devices for a period of five years from the last occurrence of substantial voting discrimination. This was a legitimate response to the problem, for which there is ample precedent in Fifteenth Amendment cases. The Act is expiring in 2007. Voting Rights Act Amendments of 1982, Pub. L. No. 97-205, S 2(b)(8), 96 Stat. 131, 133 (codified as amended at 42 U.S.C. §1973b (a)(8) (1988)) (applying 25_year expiration period from effective date of the Voting Rights Act Amendments).

89 U.S. DeP'T OF COMmerce, A NATION Online: How AmERICANS ARE EXPANDing Their UsE OF THE INTERNET 21 (2002), available at http://www.ntia.doc.gov/ntiahome/dn/anationonline2.pdf ("In September 2001 . . Internet use among Whites and Asian American and Pacific Islanders hovered around 60 percent, while Internet use rates for Blacks (39.8 percent) and Hispanics (31.6 percent) trailed behind.") PEW INTERNET \& AMERICAN LIFE PROJECT, $\begin{array}{lllll}\text { WHO'S NOT ONLINE } & 3 & \text { (2000), available }\end{array}$ http://www.pewinternet.org/reports/pdfs/Pew_Those_Not_Online_Report.pdf (reporting survey results suggesting that " $50 \%$ of whites have access; $36 \%$ of blacks have access; $44 \%$ of Hispanics have access").

${ }^{90}$ See Bush v. Gore, 531 U.S. 98, 147 (2000) (Breyer, J., dissenting) (“"[T]he ballots of voters in counties that use punch-card systems are more likely to be disqualified than those in counties using optical-scanning systems. . . . Thus, in a system that allows counties to use different types of voting systems, voters already arrive at the polls with an unequal chance that their votes will be counted."); Spencer A. Overton, A Place at the Table: Bush v. Gore Through the Lens of Race, 29 FLA. ST. L. REV. 469 ( 2001). The Internet can reduce the costs of social and political mobilization for people of color once barriers to entry are overcome. Thus, an expansion of Internet access might, in many ways, mitigate the effect of past discriminatory allocation rules on political activity by people of color. See Anupam Chander, Whose Republic, 69 U. CHI. L. REV. (forthcoming 2002) 
disenfranchisement laws disproportionately impact those disadvantaged by discriminatory allocation rules. $^{91}$ One could also assert that discriminatory allocation rules affect the racial distribution of educational opportunities, subsistence, health care, and shelter, all of which individuals need to influence political debate and cast an informed vote. ${ }^{92}$

\section{CONCLUSION}

While past racially discriminatory laws impact the distribution of substantive property rights, they also establish the framework within which individuals exercise political rights. ${ }^{93}$ As Buckley shows, resources are needed to engage in effective political communication and to participate in the democratic process. Because the value of political liberties depends on the existing distribution of economic resources, ${ }^{94}$ discriminatory allocation rules hinder the ability of people of color to forge political identities, develop alliances with others, and secure and preserve substantive rights and opportunities. Those who are not adversely impacted by these rules are better able to exercise their political liberties and secure legislative pronouncements that effectively perpetuate, and often exacerbate, racial disparities. ${ }^{95}$

Concerns about political liberties need not distract from race theorists' concerns about economic opportunity, but can fortify claims to economic entitlement. A consideration of how property functions in the political arena allows for a more comprehensive understanding of the harms of discriminatory allocation rules, and enhances the claims of race theorists. If the use of resources for politics is so important that it justifies judicial protection from excessive legislative

(reviewing CAss Sunstein, Republic.com (2001)) (observing that conventional media such as television fail "to reflect the diversity of America," and arguing that expansion of Internet access to people of color will strengthen democracy by reducing "the costs of social and political mobilization."). Contrary to the position of Professor Chander and of this Article, some commentators do not view racial disparities in Internet access as a significant problem. See Eben Moglen \& Pamela S. Karlan, The Soul of a New Political Machine: The Online, the Color Line and Electronic Democracy, 34 LoY. L.A. L. REV. 1089, 1089, 1092, 1113 (2001) (asserting that conventional concerns about the digital divide are "trivial and transitory" because "[s]ocioeconomic disparities ... have always affected the political prospects of minority voters," and that technologies may offer "new political opportunities to minority voters" because they offer "alternatives to traditional geographic districting practices.").

${ }^{91}$ See Samuel Issacharoff, Pamela S. Karlan \& Richard H. Pildes, The Law of Democracy: Legal Structure of the PoliticAl PROCESS 43 (2d ed. 2001) ("Nationally, 13 percent of black men cannot vote because of criminal records; in Alabama and Florida, nearly one in three black men are permanently disenfranchised. No other democracy appears to disenfranchise as many people due to criminal records.").

${ }^{92}$ Cf. Frank Michelman, Welfare Rights in a Constitutional Democracy, 1979 WASH. U.L.Q. 659,677 (suggesting that health and vigor, presentable attire, and shelter are "universal, rock-bottom prerequisites of effective participation in democratic representation."); Berta Esperanza Hernandez_Truyol \& Shelbi D. Day, Wealth, Inequality and Human Rights: A Formula for Reform, 34 IND. L. REV. 1213, 1232 (2001) ("“T]he political achievements of Blacks as United States citizens, and our failures, embodied in the segregation and wealth disparities that have been discussed here, cannot be isolated from one another. Undoubtedly, the right to vote means very little if one is systematically oppressed, hungry, homeless, uneducated, unemployed, underemployed, or unable to care for one's family.").

${ }^{93} \mathrm{Cf}$. Shelley v. Kramer, 334 U.S. 1, 10 (1948) ("Equality in the enjoyment of property rights was regarded by the framers of [the Fourteenth] Amendment as an essential pre-condition to the realization of other basic civil rights and liberties which the Amendment was intended to guarantee.").

${ }^{94}$ Cf. Frank I. Michelman, Process and Property in Constitutional Theory, 30 CLEV. ST. L. ReV. 577, 586 (1982) (observing that "the constitutional right of property is strictly parasitic on non-constitutional positive law").

${ }^{95}$ For a detailed discussion as to how the existing campaign finance system perpetuates racial disparities through its impact on policymaking, see Spencer A. Overton, But Some Are More Equal: Race, Exclusion, and Campaign Finance, 80 TEX. L. REV. (forthcoming 2002). 
restrictions, it follows that discriminatory allocations that interfere with the ability of people of color to use resources for politics deserve closer examination. 